\title{
The Toxicity and Antibacterial Properties of Calamus ornatus BI. Rattan Fruit
}

\author{
Heriad Daud Salusu ${ }^{1}$, Ernita Obeth ${ }^{1}$, Abdul Rasyid Zarta ${ }^{1}$, Eva Nurmarini ${ }^{1}$, \\ Hamka Nurkaya ${ }^{1}$, Irawan Wijaya Kusuma ${ }^{2}$, Enos Tangke Arung ${ }^{2 *}$ \\ ${ }^{1}$ Department of Agriculture Technology, Agricultural Polytechnic of Samarinda, Kampus Gunung Panjang, \\ Jl. Samratulangi, Samarinda 75131, Indonesia \\ ${ }^{2}$ Faculty of Forestry, Mulawarman University, Kampus Gunung Kelua, Jl. Penajam, Samarinda 75119, Indonesia \\ *Email: tangkearung@yahoo.com
}

Submitted: May 31, 2019; Acceptance: September 25, 2019

\begin{abstract}
Calamus ornatus Bl., locally known as rotan mantang or rotan seuti is one of the commercial rattan species growing in the forests of East Borneo. Its fruit is edible, like the fruits of other species of rattan, and it has been used by the local people as traditional medicine to treat stomachache or toothache. Until recently, there has not been any study investigating the benefits of the fruit for medicinal or other purposes. This research aimed to discover the bio-activity potentials of Calamus ornatus BI. fruits by identifying its toxicity level and antibacterial potentials. The parts of the fruit (pericarp, flesh, and seed) were extracted using ethanol as solvent to extract samples. The toxicity was analyzed by using the Brine Shrimp Lethality Test (BSLT) method while the antibacterial activity was tested using a well diffusion method. Low toxicity was found in the flesh, whereas the pericarp and the seed were non-toxic. Antibacterial activity against Escherichia coli was found in the pericarp and the seed, while antibacterial activity against Streptococcus mutans was found in the pericarp and the flesh.
\end{abstract}

Keywords: Antibacterial; Calamus ornatus; fruit; toxicity

\section{INTRODUCTION}

Rattan is a typical tropical plant which belongs to palmae family where it is estimated that about 600 species grow in rainforest in many parts of tropical regions (Sanusi, 2012). Rattan not only produce stem but also bears fruits, some of them are edible. However, only a small group of people know this. In East Kalimantan, rattan fruit is sold in traditional markets during fruit seasons. Traditionally, people have been using rattan fruit to cure canker sores and treat stomach pain.

One of the efforts to explore the benefits of rattan fruit is to investigate its bioactivity potential that may lead to improving human life. Bioactive components have physiological activity that can have a positive effect on human health.

The bioactivities of rattan fruit had been reported in previous studies. The fruit Calamus erectus Roxb showed bio-activity potentials which include antioxidant and antidiabetic due to high content of phenol (Ghosal and Mandal, 2013). Research on fruit of Calamus tenuis Roxb. shows that the phytochemical contents such as antioxidant and cytotocic properties found in rattan fruit were related to its bioactivity (Ahmed et al., 2014).

C. ornatus $\mathrm{Bl}$, whose fruit is edible, is one of the commercial rattans locally known as rotan mantang or rotan seuti. This rattan grows clumped and is found in many forests in East Kalimantan. This species of rattan has a large diameter and is used as raw material for rattan furniture. Its flesh is sour but edible. The size of its fruit is $3 \mathrm{~cm} \times 2 \mathrm{~cm}$ covered with brown yellow to dark brown, dull scaly skin.

The information regarding to the benefit of rattan fruit is still limited to the knowledge and experiences of local community living around the forest. Therefore, this study was aimed to collect evidence on the benefits of rattan fruit and thus, increase its value. The number of rattan growers has decreased due to the fall in the price of rattan products. Thus, extensive information on the benefit of rattan may help the industry to thrive again 
This study analyzed bioactivity properties of C. ornatus $\mathrm{Bl}$ that include toxicity and antimicrobial potentials present in pericarp, flesh and seeds. Pericarp and seeds are also investigated in this study because it is important to know the potential bioactivity that is also likely to be utilized in addition to the edible flesh of the fruit.

\section{METHODS}

\section{Plant Materials}

In this research, the fruit of $C$. ornatus $\mathrm{Bl}$. was obtain West Kutai District, East Kalimantan, Indonesia. The identification of the species was conducted in Dendrology Laboratory and analyzed in Wood Properties and Product Analysis Laboratory, State Agricultural Polytechnic of Samarinda.

The pericarp, flesh and seed from the fresh rattan fruit were separated and dried in a room with a temperature of about $25^{\circ} \mathrm{C}$ for one week before they were converted into powders. Next, the fruit powder was extracted by using maceration method with ethanol as the solvent. The powder sample was soaked in ethanol for 48 hours with the ratio of 1:10 (powder:solvent). The result from maceration was evaporated using rotary vacuum evaporator at the temperature of $30-40{ }^{\circ} \mathrm{C}$ to obtain crude extract.

\section{Toxicity Analysis}

The toxicity of rattan fruit extract was analyzed by using Brine Shrimp Test (BST) method (Kuspradini et al., 2016). The 48 hours old of shrimp larvae of Artemia salina was used to test the toxicity. A total of 10 shrimp larvae were added into the tested extract solution at the concentration of $10 \mu \mathrm{g} / \mathrm{mL}, 100 \mu \mathrm{g} / \mathrm{mL}, 250 \mu \mathrm{g} /$ $\mathrm{mL}$ and $500 \mu \mathrm{g} / \mathrm{mL}$ with 3 repetitions. After 24 hours, the number of dead shrimps in every treatment was counted. The data were analyzed using probit analysis to obtain the value of $\mathrm{LC}_{50}$. If the value of $\mathrm{LC}_{50}$ was higher than $1000 \mu \mathrm{g} / \mathrm{mL}$, it would be categorized as toxic.

\section{Antibacterial}

Antibacterial properties was tested using agar well diffusion method (Arung et al., 2017). Antibacterials were tested against Escherichia coli and Streptococcus mutans with chloramphenicol as antibiotic against the bacteria that was used as a positive control and acetone as negative control. An amount of $20 \mathrm{~mL}$ of nutrient agar was placed in the placed in sterilized petri dish. Then, $100 \mu \mathrm{L}$ of bacteria were inoculated by using spread plate method and spread evenly in the dish.
Next, the well holes were filled with the extract sample with the concentration of $25 \mu \mathrm{g} /$ well, $50 \mu \mathrm{g} /$ well, 100 $\mu \mathrm{g} / \mathrm{well}$ and $200 \mu \mathrm{g} / \mathrm{well}$ and incubated for 24 hours at the temperature of $37^{\circ} \mathrm{C}$. The observation was made by measuring the inhibitory diameter which formed a clear area around the well holes.

\section{RESULTS}

\section{Toxicity}

Toxicity assay was made using Brine Shrimp Lethality Test (BST) which was estimated based on the number of shrimp larvae of Artemia salina that died after 24 hours in the extract solution. This is an early stage test in preclinical toxic properties. This method has advantages such as quick execution time, relatively cheap cost, simple workmanship, the ability to keep the eggs stay alive in dry conditions for several years. In addition to BSLT test, another method was used to screen the initial compounds that were efficacious as anti-cancer (Meyer et al., 1982). The higher the toxicity level of plant secondary metabolites, with smaller $\mathrm{LC}_{50}$ values, the more potential the plant is to be used in anticancer treatment.

Figure 1 shows that the higher the extract concentration, the higher the mortality of the shrimp larvae.

The level of toxicity in each part of rattan fruit extract was determined based on the value of Lethal Concentration of $50 \%\left(\mathrm{LC}_{50}\right)$, i.e. the amount of concentration that could kill $50 \%$ of the organism in the treatment, in this case the shrimp larvae of Artemia salina. The $\mathrm{LC}_{50}$ value was estimated using probit analysis where the $\mathrm{LC}_{50}$ value which was lower than $1000 \mu \mathrm{g} / \mathrm{mL}$ showed the presence of toxicity activities in the extract solution (Sautron \& Cock, 2014). The result of calculation of $\mathrm{LC}_{50}$ is displayed in Table 1:

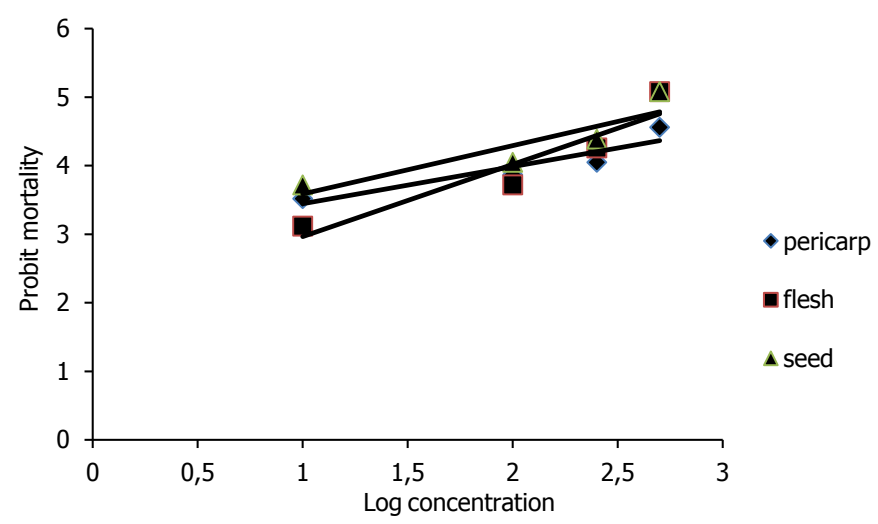

Figure 1. The correlation between extract concentration of the sample and the mortality of the shrimp larvae 
Table 1. $\mathrm{LC}_{50}$ value of fruit extract of $C$. ornatus $\mathrm{BI}$.

\begin{tabular}{ccc}
\hline Samples & $\mathrm{LC}_{50}(\mu \mathrm{g} / \mathrm{mL})$ & Notes \\
\hline Pericarp & 7427.60 & Non active \\
Flesh & 854.45 & Active \\
Seed & 1009.85 & Non active \\
\hline
\end{tabular}

The assay result based on the $\mathrm{LC}_{50}$ value showed that only the flesh part was toxic because the value of its $\mathrm{LC}_{50}$ was lower than $1000 \mu \mathrm{g} / \mathrm{mL}$ whereas the pericarp and seed were non-toxic because their $\mathrm{LC}_{50}$ value were higher than $1000 \mu \mathrm{g} / \mathrm{mL}$. The classification of toxicity activity based on the value of $\mathrm{LC}_{50}$ is divided into five categories: Non-toxic (higher than $1000 \mu \mathrm{g} /$ $\mathrm{mL})$; low $(500-1000 \mu \mathrm{g} / \mathrm{mL})$, moderate $(200-500 \mu \mathrm{g} /$ $\mathrm{mL})$, high $(100-200 \mu \mathrm{g} / \mathrm{mL})$ and very high $(1-100 \mu \mathrm{g} /$ $\mathrm{mL}$ ) (Mungenge et al., 2014). It is furthermore stated that petroleum ether and chloroform solvents yield an extract with a moderate toxicity and methanol yields an extract with a low toxicity.

\section{Antibacterial}

The antibacterial activities in the extracts of pericarp, flesh and seed of $C$. ornatus $\mathrm{Bl}$. were assayed against the Escherichia coli bacterium, i.e. the bacterium which usually lives in human and animal intestines that can cause mild diarrhea or a serious intestinal infection such as diarrhea, stomachache and fever. They were also assayed against Streptococcus mutans, i.e. a bacterium which can be found in human oral cavity which significantly contributes to the tooth decay. The method used for the assay was the agar well diffusion and chloramphenicol (an antibiotics used to fight bacteria) as the negative control. The result of the assays showed different activities in each fruit part observed (Table 2).

Table 2 shows that the higher the extract concentration, the higher the antibacterial activity. The assay results also implied that there are different inhibitory zones in each treatment. The growth of $E$. coli bacterium was inhibited in pericarp and seed extracts but it was not the case in the flesh extract. In the pericarp extract, the inhibition activity began to occur at the lowest concentration $(25 \mu \mathrm{g} /$ well $)$ and it increased following the increase in extract concentration, where the highest inhibitory zone was found at the concentration of $200 \mu \mathrm{g} /$ well, namely $16.11 \mathrm{~mm}$. In the meantime, in the seed extract, the inhibition began at the concentration of $50 \mu \mathrm{g} /$ well, but it was still lower than that in the positive control (Chloramphenicol) with an inhibitory zone of around $41.00 \mathrm{~mm}$. The inhibition against $S$. mutans bacterium occurred in the pericarp and
Table 2. Antibacterial activities in the fruit extract of $C$. ornatus Bl.

\begin{tabular}{lcccc}
\hline \multirow{2}{*}{$\begin{array}{c}\text { Species of } \\
\text { bacteria }\end{array}$} & $\begin{array}{c}\text { Concentration } \\
(\mu \mathrm{g} / \text { well })\end{array}$ & \multicolumn{3}{c}{$\begin{array}{c}\text { Diameter of inhibitory } \\
\text { zones }(\mathrm{mm})\end{array}$} \\
\cline { 3 - 5 } & 25 & 8.00 & 0.00 & 0.00 \\
\hline Escherichia coli & 50 & 9.44 & 0.00 & 9.55 \\
& 100 & 13.40 & 0.00 & 13.67 \\
& 200 & 16.11 & 0.00 & 15.55 \\
& 25 & 0.00 & 8.55 & 0.00 \\
Streptococcus & & & & \\
mutans & 50 & 0.00 & 9.11 & 0.00 \\
& 100 & 8.00 & 9.89 & 0.00 \\
& 200 & 12.00 & 13.33 & 0.00 \\
Chloramphenicol & 10 & 41.66 & 41.00 & 41.56 \\
\hline
\end{tabular}

flesh extracts but not in the seed extract. The inhibition in the flesh extract began at the lowest concentration $(25 \mu \mathrm{g} /$ well $)$ and continued until it reached the highest concentration $(200 \mu \mathrm{g} /$ well) with an inhibitory zone of $13.33 \mathrm{~mm}$. The inhibition in the pericarp extract occurred at the concentration of $100 \mu \mathrm{g} /$ well and 200 $\mu \mathrm{g} /$ well where their inhibitory zones were $8.00 \mathrm{~mm}$ and $12.00 \mathrm{~mm}$ respectively. It is still lower compared to the positive control (Chloramphenicol) with an inhibitory zone of $41 \mathrm{~mm}$.

\section{Discussion}

Toxicity testing was performed to know the toxicity level of the extracts in order to determine the extent of their further utilization or other benefits based on their toxicity levels. Bioactive compounds are almost always toxic at high doses, therefore the in vivo killing power of compounds against animal organisms can be used to filter plant extracts that have bioactivity. One of the organisms that is suitable for this is brine shrimp (Mungenge et al., 2014).

Based on the data in Table 3, it can be said that this study has revealed that the toxicity level of flesh extract of $C$. ornatus $\mathrm{Bl}$. was low. Mungenge et al. (2014) suggests that toxicity is influenced by the contents of flavonoids, tannins, alkaloids and saponins. This is in line with Salusu et al. (2018) who discovered that the phytochemical component found in Calamus ornatus pericarp contains flavonoids, alkaloids, tannins and triterpenoids, the fruit flesh contains tannins and triterpenoids, and the seeds contain flavonoids, tannins and triterpenoids.

Therefore, it was suspected that toxicity level in the flesh extract was induced by tannin and triterpenoid 
contents since the concentration of these two compounds might be higher in the flesh compared to those in the seed and pericarp. Triterpenoid is known to have an important role as an anticancer. The anticancer mechanism of triterpenoids is based on their antioxidant properties that is associated with their ability to scavenge free radicals, inhibit the enzymes involved in ROS formation, and block the oxidation of cellular and extracellular compounds (Hamidi et al., 2014).

Tannins are present in roots, wood, bark, leaves, and fruit. It protects plants from predators and also helps in regulating plant growth. Tannin prevents the harvest of unripe fruit because it gives a bad taste for wild animals. In addition to that, it is also active in photosynthesis and physiological processes of fruit formation and maturation. However, the amount of tannins is reduced as the fruit ripens. Therefore, high tannin concentration is found in immature fruit (Maitera et al., 2018). Nevertheless, this requires further study to identify which active concentrations and compounds influence the toxicity level in the flesh of $C$. ornatus $\mathrm{BI}$.

The inhibition against $S$. mutans bacterium occurred in the pericarp and flesh extracts, but did not occur in the seed extract. The inhibition in the flesh extract began at the lowest concentration $(25 \mu \mathrm{g} /$ well $)$ and continued until it reached the highest concentration (200 $\mu \mathrm{g} /$ well) with an inhibitory zone of $13.33 \mathrm{~mm}$ whereas the inhibition in the pericarp extract occurred at the concentration of $100 \mu \mathrm{g} /$ well and $200 \mu \mathrm{g} /$ well where their inhibitory zones were $8.00 \mathrm{~mm}$ and $12.00 \mathrm{~mm}$ respectively. This is still lower compared to the positive control (Chloramphenicol) with an inhibitory zone of $41 \mathrm{~mm}$. Thus, the increased concentration of extract increases antibacterial activity. In general, the data showed that the pericarp was potential to inhibit the two species of tested bacteria because it contains alkaloids. This is in line with the previous study (Djeussi, 2013) which states that alkaloids can serve as antimicrobial because it disrupt cell division of bacterium. Alkaloids are able to inhibit the growth of $E$. coli bacterium at the concentration of $25 \mu \mathrm{g} / \mathrm{mL}$ (Guil-Guerrero et al., 2016). In addition, alkaloid also influences antimicrobial activity against S. mutans bacteria (Shetty et al., 2016). Alkaloid has an antibacterial ability because it has a quartener aromatic group capable of interacting with DNA. Alkaloids are also able to disrupt the integrity of peptidoglycan components in bacterial cells. Peptidoglycan is a component of cell wall in bacteria that any disruption in peptidoglycan will inhibit wall layer formation and could lead to cell death (Rahman et al., 2017).

Data also showed that pericarp and the seed had better antibacterial activities against $E$. coli compared to that of the flesh. However, in terms of fighting against S. mutans bacteria, while the seed showed zero activity, the flesh performed better than that of the pericarp.

\section{CONCLUSION}

The findings of this study revealed that each part $C$. ornatus $\mathrm{Bl}$. fruit had bioactivity potentials. Low toxicity potential was found in the flesh while the pericarp and the seed were nontoxic. Antimicrobial activity against $E$. coli bacterium was found in the pericarp and the seed while antimicrobial activity against $S$. mutans was found in the pericarp and the flesh. Because the pericarp had better bioactivity than the seed and the flesh, particularly in terms of antibacterial, it is necessary to do further study to identify and isolate the active compounds of the fruit of $C$. ornatus, especially the compounds that serve as antibacterial agent to maximize the benefits of this fruit to human health.

\section{ACKNOWLEDGMENT}

This paper is part of a research funded by the Directorate of Research and Development, Directorate General of Higher Education; Ministry of Research, Technology and Higher Education, Republic of Indonesia, through the Program for Doctoral Dissertation Grants scheme 2017. The authors express gratitude for the funding of this research and also to all those who have provided support.

\section{CONFLICT OF INTEREST}

Authors declare that there was no conflict interest between authors and the founder.

\section{REFERENCES}

Ahmed, Z. U., Bithi, S. S., Minhozur, Khan, M. R., Hossain, Md. M., Sharmin, S. \& Roni, S. R. (2014). Phytochemical screening, antioxdiant and cytotoxic activity of fruit extract of Calamus tenuis Roxb. Journal of Coastal Life Medicine, 2(8), 645-650. http://doi.org/10.12980/ JCLM.2.201414D74

Arung, E. T., Kusuma, I. W., Christy, E. O., Shimizu, K., \& Kondo, R. (2009). Evaluation of medicinal plants from Central Kalimantan for anti melanogenesis. J. Nat. Med., 63(4), 473-480. http://doi.org/10.1007/s11418-0090351-7

Djeussi, D. E., Noumedem, J. A. K., Seukep, J. A., Fankam, A. G., Voukeng, I. K., Simplice, B., Tankeo, S. B., Nkuete, A. \& Kuete, V. (2013). Antibacterial Activities of Selected 
Edible Plants Extracts against Multidrug-resistant Gramnegative Bacteria. BMC Complementary and Alternative Medicine, 13, 164-170. http://doi.org/10.1186/14726882-13-164

Ghosal M. \& Mandal, P. (2013). In-vitro antidiabetic and antioxidant activity of Calamus erectus Roxb. fruit: a wild plant of Darjeeling Himalaya. International Journal of Pharma and Bio Sciences, 4(2), 671-684.

Guil-Guerrero, J. L., Ramos, L., Moreno, C., Zúñiga-Paredes, J. C., Carlosama-Yepez, M. \& Ruales, P. (2016). Antimicrobial activity of plant-food by-products: a review focusing on the tropics. Livestock Science, 189, 32-49. http://doi.org/10.1016/j.livsci.2016.04.021

Hamidi, M. R., Jovanova, B. \& Panovska T. K. (2014). Toxicological evaluation of the plant products using brine shrimp (Artemia salina L.) model. Macedonian Pharmaceutical Bulletin, 60(1), 9-18.

Kuspradini, H., Rosiarto, A. M., Putri, A. S. \& Kusuma, I. W. (2016). Antioxidant and toxicity properties of anthocyanin extracted from red flower of four tropical shrubs. Nusantara Bioscience, 8, 135-140.

Maitera, O. N., Louis, H., Oyebanji, O. O. \& Anumah, A. O. (2018). Investigation of tannin content in Diospyros mespiliformis extract using various extraction solvents. Journal of Analytical \& Pharmaceutical Research, 7(1), 55-59. http://doi.org/10.15406/ japlr.2018.07.00200

Meyer, B. N. Ferrigni, N. R., Putnam, J. E., Jacobsen, L. B., Nicholas, D. E. \& McLaughin, J. L. (1982). Brine shrimp: a convenient general biossay for active plant constituents. Planta Medica, 45, 4-31.
Mungenge, C., Zimudzi, C., Zimba, M. \& Nhiwatiwa, T. (2014). Phytochemical screening, cytotoxicity and insecticidal activity of the fish poison plant Synaptolepis alternifolia oliv. (Thymelaeaceae). Journal of Pharmacognosy and Phytochemistry, 2(5), 15-19.

Rahman, F. A., Haniastuti, T. \& Utami, T. W. (2017). Phytochemical screening and antibacterial activity of ethanol extract of soursop leaf (Annona muricata L.) on Streptococcus mutans ATCC 35668. Indonesian Dentistry Magazine, 3(1), 1-7.

Salusu, H. D., Aryani, F., Zarta, A. R., Budarso, E., Kusuma, I. W. \& Arung, E. T. (2018). Antioxidant assay of the ethanolic extract of three species of rattan fruits using DPPH method. J. Trop. Pharm. Chem., 4(4), 154-162. http://doi.org/10.25026/jtpc.v4i4.170

Sanusi, D. (2012). Rattan, Wilderness of Indonesia. Surabaya: Brilian Internasional.

Sautron, C. \& Cock, I. E. (2014). Antimicrobial activity and toxicity of Syzygium australe and Syzygium leuhmannil fruit extracts. Pharmacognosy Communications, 4(1), 53-60. http://doi.org/10.5530/pc.2014.1.8

Shetty, S. B., Mahin-Syed-Ismail, P., Varghese, S., ThomasGeorge, B., Thajuraj, P. K., Baby, D., Haleem, S., Sreedhar, S. \& Devang-Divakar, D. (2016). Antimicrobial effects of Citrus sinensis peel extracts against dental caries bacteria: an in vitro study. J Clin Exp Dent, 8(1), e70-7. http://doi.org/10.4317/jced.52493 